\title{
MOCENSKÝ KALKUL JAKO KONSTANTA I PROMĚNNÁ LIDSKÉHO PŘíBĚHU V KONTEXTU POJETÍ KRÁLOVSKÉ MOCI, ARCHETYPU A OSUDU PŘEMYSLA OTAKARA II. V ZRCADLE ŠKOLY ANNALES'
}

\author{
JANA Ǩ̌́́ŽOVÁ \\ Fakulta humanitních studií Univerzity Karlovy \\ jana-krizova@seznam.cz
}

\begin{abstract}
The power calculus as a constant and a variable of human story. The concept of royal power, the archetype and the fate of Premysl Otakar II in the mirror of the school Annales

In this following text I take an excursion into my emerging dissertation and here I present some basic considerations about the issue of depicting the image of personality of the fifth Czech king on the basis of literary sources. When examining the information source, I also proceed from the teachings of the main representatives of the Annales school, which mean from the point of view of historical-anthropological.
\end{abstract}

Keywords: Royal power - human story - archetyp - Annales school - Přemysl Otakar II.

„Objevovat středověké rukopisy byla pro mě veliká radost (...), ve vyhledávání dokumentů a $v$ dešifrování těch $z$ nich, jimž se ríká prameny, spočívají veškeré dějiny. "2

Můj př́spěvek je exkurzem do vznikající dizertační práce, v níž jsem si stanovila za úkol promýšlet historiograficky problémové uchopení obrazu osobnosti v pořadí pátého českého krále Přemysla Otakara II. (* 1233[?]-† 26. srpna 1278)33 na základě literárních pramenů. ${ }^{4}$ Ráda bych $\mathrm{v}$ něm nastínila některé mé základní úvahy při vstupu do pro-

1 Označení textu koresponduje s názvem kvalifikační práce Mocenský kalkul jako konstanta i proměnná lidského př́běhu. Pojetí královské moci, archetyp a osud Přemysla Otakara II. v zrcadle školy Annales, jež vzniká na půdě Fakultě humanitních studií UK a navazuje na obhájenou diplomovou práci Zobrazení postavy Přemysla Otakara II. v literárních pramenech (do třetí ćtvrtiny 14. století) a nedokončenou práci Přemysl Otakar II. jako archetyp v literárních pramenech. Tento článek vznikl v rámci projektu Specifického vysokoškolského výzkumu 26060701 (Sociálně antropologický výzkum) na bázi příspěvku vysloveného na konferenci Ústavu pro dějiny umění UK 2019, nazvané Překračování hranic II.

2 Jacques Le Goff, Hledání středověku, Praha 2005, s. 31.

3 Markrabě moravský od roku 1247, vévoda rakouský v období let 1251-1276, štýrský mezi lety 1261 až 1276, korutanský a kraňský v letech 1269-1276 a chebský pán.

4 Oporou jsou mi, kromě sekundární literatury, vyprávěcí prameny vzniklé na našem území do třetí čtvrtiny 14. století. Byly psány převážně latinsky, časově objímají celé studované údobí. Výjimkou je česky psaná rýmovaná Kronika česká tak řečeného Dalimila. Řešené období analisticky mj. postihují tzv. Druzí pokračovatelé Kosmovi, zpracování problematiky je známé též ze Zbraslavské kroniky. Písemnými doklady vzniklými v době Karla IV., které zachycují dané období, jsou Kronika Františka Pražského, navazující na analistické vyprávění pražské kapituly, a Přibíka Pulkavy z Radenína Kro- 
blematiky, jež mi dále slouží jako podstatné východisko k mému dalšímu bádání. Při zkoumání pramenné základny ve své práci primárně vycházím, jak už název napovídá, $\mathrm{z}$ učení hlavních představitelů školy Annales, tedy z hlediska historickoantropologického. Výzkumu doposud dominují a zároveň jej se zvoleným př́stupem propojují otázky, jako např́iklad a) jaké jsou aspekty zachycující ztvárnění panovníkovy osobnosti ve smyslu kupř́kladu plnění nároků - morálních a jiných - na jeho osobu (mimo jiné „překročení mezí": opozice vůči otci, nemanželský vztah, střet se šlechtou) či b) atributy, jakými jsou jednak jeho skutky a jednak okolnosti, které ho k těmto činům vedly (překračování hranic jako „kampaně“, mimo jiné válečná tažení do Prus či Bavor). Jako kontrapunkt hledám v kontextu nejen hluboce zakořeněných struktur, jimiž se daná společnost (a v první řadě její panovník) řídí - příčiny poměrně časného vzniku nového „pozitivního“ mýtu českých dějin o Přemyslu Otakaru II., tedy do jaké míry při tvorbě kronikářského záznamu zasahovaly do panovníkova obrazu či jej překračovaly mocenský kalkul a topoi. ${ }^{5} \mathrm{~V}$ neposlední řadě považuji za zajímavé zkoumat platnost Blochovy premisy přeměny a zániku kolektivní iluze či koncept trojí úrovně historického času Fernanda Braudela. Oslovuje mne i další z tezí, formulovaná představitelem školy Annales Jacquesem Le Goffem, a to „osvětlit jednu kulturu ve všech jejích dimenzích“ $\mathrm{z}$ hlediska technologie, ekonomie, politických institucí, sociálních struktur a vztahů, nadto zastřešených „historickým zájmem, zrozeným z velké části ze spojení dějin se společenskými vědami“ ${ }^{6}$

\section{Vstup českého státu do středověkých evropských dějin ${ }^{7}$}

Poté, co zkraje středověku naskicoval Karel Veliký novou mapu Evropy, bylo české knížectví východní periferií Západořímské říše. Ještě mnohá staletí, a nic na tom nezměnila ani Zlatá bula sicilská, bylo území Čech a Moravy západní výspou křestanství. Viděno evropskýma očima, pohraniční tvrz ovládaná západními Slovany, kteří sice přijali latinskou kulturu, leč přesto zaostávali za „vyspělou“ Evropou téměř ve všech oblastech. At šlo o zemědělství, řemesla, vzdělání, obchod, ${ }^{8}$ nebo životní styl a kulturu. Teprve dynastie Přemyslovců 13. století, a nejvýrazněji pak vláda Přemysla Otakara II., dala svými refor-

nika česká, všímající si osobnosti Přemysla Otakara II., stejně jako panovnického ideálu, prostřednictvím vladařových skutků. Obě díla jsou dedikována císaři Karlu IV. Při excerpci prozatím nejčastěji vycházím především z Emlerovy edice (Fontes rerum Bohemicarum II-V, ed. Josef Emler, Praha 1874-1893), jež oproti novějším kritickým vydáním například v Druhých pokračovatelích Kosmových přihlíží k umělému rozdělení vyprávěcích pramenů na Př́běhy krále Václava I., Příběhy krále Přemysla Otakara II. a Zlá léta po smrti krále Přemysla Otakara II.

5 Zdeněk Kratochvíl - Jan Bouzek, Proměny interpretací, Praha 1996, s. 127nn.

6 Jacques Le Goff, Kultura středověké Evropy, Praha 1991, s. 741.

7 Obecný úvod se z českých souborných prací mimo jiné opírá jak o Novotného a Šustovy České dějiny, Šustovy Dvě knihy českých dějin, Palackého Dějiny národa českého, tak i publikace např́iklad Zdeňka Fialy, Josefa Janáčka či Josefa Žemličky. - Václav Novotný, České dějiny I, část 4, Praha 1937, s. passim. - Josef Šusta, České dějiny II, část 1, Praha 1935, s. passim. - Josef Šusta, Dvě knihy českých dějin: kus středověké historie našeho kraje 1, Praha 1926, s. passim. - František Palacký, Dějiny národa českého v Čechách a na Moravě dle puvodních pramenův II, Praha 1877, s. passim.

8 Jacques Le Goff, Peníze ve středověku: historicko-antropologická studie, Praha 2012, s. 46-47. Obecně má Le Goff za to, že 13. století bylo věkem nakloněným penězům, nicméně zároveň uvádí, že výnosnost stř́ibrných dolů v tomto století nedosahovala úrovně následujících období. Zmiňuje i technický pokrok, šíření peněz v kontextu rozmachu obchodu. Mezi příklady nových či více využívaných míst těžby připomíná i Jihlavu na Moravě. 
mami, kolonizačním úsilím, využitím nerostných zdrojů - především stříbra ${ }^{9}$ - jednoznačnou odpověd'. „Dohánění standardů“ pokročilejší Evropy je toho jasným dokladem. Je tak první historickou paralelou naší aktuální současnosti.

Evropská politika poslední dynastie Přemyslovců (a později i Lucemburků) však nepůsobila tlakem na české prostředí, aby si v něm vynutila svou realizaci, ačkoli $\mathrm{k}$ tomu byly vytvořeny všechny potřebné předpoklady: souvislé a dlouhodobé osídlení ${ }^{10}$ společného prostoru nevytvořilo ještě zdaleka tak silné jazykové vazby tohoto společenství. V Evropě šlo o nijak řídký jev, od Iberského poloostrova až po Skandinávii. V českých zemích to však byl přece jen pozoruhodný úkaz, zvláště za vlády královských Přemyslovců. Čtvrt století leželo politické těžiště římské říše za panování Přemysla Otakara II. v českém království. Život u dvora dosáhl pozoruhodné kulturní vyspělosti. Politická expanze zasáhla Balt, Alpy i Jadran. Přestavba státní správy dosáhla nevídaných rozměrů, propojila pevněji nejen tradiční české a moravské území, nýbrž formovala i současné Rakousko. Jazyk - jako jedna z primárních forem komunikace - zprostředkovával nejenom kulturní vzory, ale i naprríklad novou techniku. Zásluhou kolonizace se rozvíjelo zemědělství a díky zakládání měst i výrobní základna. Odborné názvosloví řady řemeslných oborů se $\mathrm{v}$ češtině konstituovalo především z němčiny, nejinak tomu bylo v oblasti právní, správy státu či obchodu.

Křestanská Evropa posunula své hranice na východ. Zřetelný posun mocenského centra k východu doprovázela právní reforma i úsilí o reformu finanční, s Le Goffem řečeno, „(...) Západ v prodlouženém 13. století doznal rozvoje vnitřního i zahraničního obchodu, díky němuž můžeme hovořit o obchodní ,revoluci“."11 To vše se odehrávalo i překračováním hranic - diplomatických, politických, společenských i lidských.

\section{Vzestup českého státu}

Osud Přemysla Otakara, v pořadí druhého s tímto jménem v přemyslovském rodu a pátého jako krále českého, se neodehrává od roku 1232 nebo 1233, ${ }^{12}$ kdy se tento český panovník narodil, ale začíná o řadu desetiletí dříve. V politické rovině je možné tento úsek starších českých dějin ohraničit vročením 1212 - mezníkem, kdy byl Fridrichem II. Švábským v Basileji upraven Zlatou bulou sicilskou poměr Čech k říši (za vlády Přemyslova děda Přemysla Otakara I., vládl 1197-1230). Český stát se následně stal jednou z evropských velmocí a přemyslovská dynastie se v Evropě zařadila mezi čelné panovnické rody. ${ }^{13}$ Vzestup pokračoval i za vlády syna Přemysla Otakara I. - Václava I. (1230-1253) a vnuka Přemysla Otakara I. - Přemysla Otakara II. (1253-1278). Stále

9 Ibidem, s. 46. Co se týče movitých osob, Le Goff mimo jiné připomíná, že „(...) ve společnosti, založené především na vztahu $k$ půdě, bylo pozemkové vlastnictví hlavním cílem snažení, (...) v době rozmachu měst měla rostoucí význam péče o jejich bezpečnost, a nakonec peníze (...) byly vynaloženy na zbožné účely“.

10 Ludmila Fialová a kol., Dějiny obyvatelstva českých zemí, Praha 1998, s. 35n.

11 Le Goff, Penize (pozn. 8), s. 46.

12 Josef Žemlička, Přemysl Otakar II.: král na rozhraní věkư, Praha 2011, s. 88. - Zdeněk Fiala, Přemyslovské Čechy: Český stát a společnost v letech 995-1310, Praha 1975, 159nn.

13 Např́klad Josef Janáček, Přemysl Otakar II., in: idem, Velké osudy, Praha 1972, s. 10. - Josef Žemlička, Přemysl Otakar I.: panovník, stát a česká společnost na prahu vrcholného feudalismu, Praha 1990, s. 106-132. - Šusta, Dvě knihy (pozn. 7), s. 132nn. 
lepší postavení v mezinárodněpolitickém životě však bylo založeno spíše na hmotné převaze českého státu než převaze kulturní. ${ }^{14}$ Šlo kupř́ikladu o stupňování kontaktů s Porýním, Podunajím, Flandry i se severoitalskými městy, které se mimo jiné opíralo o čilé obchodní styky podpořené vývozem českého stř́bra či platbou českým stříbrem. ${ }^{15}$ Bylo silně ovlivněné uplatněním Přemyslovy výbojné zahraniční politiky, vždyt’ „Praha byla od 10. do 15. století jedním z velkých středisek křestanské Evropy“16. Vnitropolitické zájmy byly určeny zejména specifiky „vnitřní a vnějši“ kolonizace. ${ }^{17}$ Možná by se místo pojmu kolonizace spíše hodilo argumentovat novým osidlováním v důsledku zemědělské evoluce. Přechod od pastvy v lesních podrostech na pastvu na lučinách, od dvojpolního hospodářství k trojpolnímu, nový způsob zapřahání tažných zvířat i nové technické prostředky k orbě či jejich masivnější využívání, to vše byly předpoklady $\mathrm{k}$ větší diferenciaci výroby na zemědělskou a řemeslnou, jež pokračovala diverzifikací specializovaných odvětví. Rovněž transformace barterových ekonomických vztahů na vztahy finanční podpořila růst moci šlechty i lavinovitě se šírícího městského patriciátu. Peníze již přestávají sloužit povětšině tezauraci a rozvíjí se jejich směna. - A silná města by samozřejmě nemohla vznikat bez vyšší produktivity polního hospodářství. Hustší osídlení a kultivace obchodních cest směřovaly k tomu, že předmětem obchodu už přestávalo být - vzhledem k rentabilitě - výhradně luxusní zboží, ale stále častěji se objevovaly i běžnější řemeslné produkty. ${ }^{18}$

Vedle všech těchto aspektů, podporujících zcela určitě vnější stabilitu a sílu českého státu, spatříme i hledisko čistě společenské, pro něž je typická proměna společenských vztahů ve 13. století. ${ }^{19}$ Tato proměna souvisí z hospodářského hlediska s rozkladem hradské soustavy a vznikem nových sídelních forem - měst - a zejména pak s vytvořením privilegované skupiny lidí kolem panovníka. Takto vzniká pozemková šlechta, která již existuje s ekonomickým zázemím, a proto nezávislá na centrálním „přerozdělování přebytků - důchodů (renty). Už tedy samostatná, šlechta vytvořila, podpořila a později zcela ovládla i nový správní systém. ${ }^{20}$

Přemysl Otakar II. se ale rozhodně nehodlal smírít s její rozpínavostí21 (a nejenom on, ale i církev a posléze i města) a snažil se celý proces zvrátit. To byl důvod reformy státní správy. Král ale „přehlédl“ skutečnost, že vývoj v běhu století pokročil. Tehdejší systém organizace raného středověkého státu, nyní již silně parazitující a znamenající latentní nebezpečí pro panovníkovy mocenské záměry, nebylo možné už vhodně a efek-

14 Josef Janáček, Český stát a Evropa ve 13. století, Folia Historica Bohemica I, 1979, s. 16nn.

15 Jiří Spěváček, K některým problémům hospodářského a sociálního vývoje v českých zemích v předhusitském období, Folia Historica Bohemica III, 1981, s. 7-76. - Josef Janáček, Stř́bro a ekonomika českých zemí ve 13. století, Československý časopis historický XX, 1972, s. 875-906.

16 Le Goff, Kultura (pozn. 6), s. 11.

17 Josef Žemlička, K charakteristice středověké kolonizace v Čechách, Československý časopis historický XXVI, 1978, s. 58-81. - A ani např́klad Le Goff neopomíná mimořádný rozmach Kutné Hory, stejně jako příchod jak německých horníků, tak i horních podnikatelů z německých oblastí říše. Le Goff, Peníze (pozn. 8), s. 53.

18 Dušan Třeštík, Věk „středu“ a naše kultura, in: Pavel Spunar et al., Kultura středověku, Praha 1972, s. 24-25.

19 Jacques Le Goff, Středověká imaginace, Praha 1998, s. 32nn.

20 Josef Žemlička, Společenský a hospodářský vývoj v době posledních Přemyslovců, in: Kolektiv autorů, Umění doby posledních Přemyslovců, Roztoky u Prahy 1982, s. 17-21. - Dušan Třeštík, Proměny české společnosti ve 13. století, Folia Historica Bohemica I, 1979, s. 131-154.

21 Ze základní literatury mj. Novotný, České dějiny I (pozn. 7), s. 405nn. 
tivně využít. Při tomto hledání nové vládní formy vznikly ostré spory se šlechtickými rody, na které také Přemysl Otakar II. draze doplatil - 26. srpna 1278 - svým životem na Moravském poli. ${ }^{22}$

\section{Kulturní proměny, ideál rytî́rské kultury}

$\mathrm{V}$ tomto století však změny neprobíhaly pouze v rovině politické, ekonomické a sociální, ale samozřejmě i kulturní. Očividné jsou znaky nové architektury - gotiky šířené stavebními hutěmi burgundských cisterciáků. Architektura spolu s uměním, jež do Čech přichází ze západní Evropy přes německé území, je ve středoevropském regionu hojně podporována. ${ }^{23}$ Začíná zlatý věk rytířství - s turnaji, hrdinskými a milostnými písněmi. ${ }^{24}$ V českých zemích se šiŕí velmi rychle, zprvu jde o módu, teprve později se stává životním ideálem.

Rytířství ovšem neznamenalo jen změnu šlechtických mravů. Před nástupem tohoto životního stylu v druhé polovině 12 . století se mravy šlechty, vladykůa jejich „kmánského" okolí zjevně nelišily. Nové etické hodnoty, které se vlivem rytířství pocházejícího z Francie šířily, znamenaly nový - a věřme, že lepší - úděl ženy, alespoň ve vyšší společnosti. Nový etický kodex jim totiž přinášel vyhraněné postavení. Dvornost mužů a milostné písně ilustrovaly ústup od poměru majetnického až otrockého ke vztahu, v němž si muž musel přízeň ženy vydobýt dvorností, statečností v boji a turnajích, bohatstvím získaným na poli vojenském i jemnými finesami nových norem chování. Od ženy se očekávala věrnost, ušlechtilé trávení volného času hudbou nebo výšivkami, trpělivost při čekání na návrat svého reka v době vojenských tažení, ale i to, že i samy ženy měly jistou možnost volby i vyjádření názoru: svou květinou nebo šátkem odměňovaly na turnajích nejudatnějšího rytíře. Rytír byl zbožný, dbalý cti, pevného slova a dle tehdejších mravů také „kulturni“. Milostné písně a hrdinský epos jako by celý tento proces rámovaly.

Rovněž nemůže být pochyb, že by se rytířský ideál nedotkl představ o ideálním panovníkovi. Panovník musel být králem rytírư, a to ve všech směrech. Přemysl Otakar II. měl možnost se takovým rytířem rytírư stát. Dostalo se mu totiž stejné výchovy jako jeho staršímu bratru Vladislavovi - prvorozenému synu Václava I. Oba vyrůstali v dvorském prostředí, kde vzkvétala již zmíněná rytířská kultura. ${ }^{25}$ Navíc Přemysl Otakar II. byl fyzicky zdatný, ${ }^{26}$ což ho samo o sobě předurčovalo k úspěšné rytířské kariéře. Teprve

22 Šusta, České dějiny II (pozn. 7), s. 241-284. - Střet u Suchých Krút komentuje v hesle o Rudolfovi Habsburském i Le Goff: „(...) a odňal českému králi Otakarovi Rakousy, Štýrsko, Korutany a Kraňsko (bitva na Moravském poli, 1278). Z tohoto di̊vodu je možno ho považovat za zakladatele moci Habsburkì." Le Goff, Kultura (pozn. 6), s. 466.

23 Jiř́ Kuthan, Gotická architektura v jižních Čechách: Zakladatelské dílo Přemysla Otakara II., Praha 1975. - Idem, Architektura v přemyslovském státě, in: Kolektiv autorů, Umění (pozn. 20), s. 181nn. - Idem, Česká architektura v době posledních Přemyslovců: Města - hrady - kláštery - kostely, Vimperk 1994. - Klára Benešovská (ed.), Královský sňatek: Eliška Přemyslovna a Jan Lucemburský 1310, Praha 2010. - Eadem (ed.), Imago Imagines I-II: Výtvarné dílo a promèny jeho funkcí v českých zemích od 10. do první třetiny 16. století, Praha 2020.

24 Wojciech Iwańczak, Po stopách rytírských př́běhů, Praha 2001, s. 19nn. - Johan Huizinga, Podzim středověku, Praha 2010, s. 31nn.

25 Le Goff, Kultura (pozn. 6), s. 316-323. - Maria Ossowska, Ethos rycerski i jego odmiany, Varšava 1973, s. 91-153.

26 Srov. František Palacký, Dějiny (pozn. 7), s. 4-5. 
smrtí bratra (zemřel roku 1247, bez potomků) se před Přemyslem Otakarem II. otevřela možnost stát se králem. Ovšem v dětství rozvíjené vlastnosti a dovednosti, stejně jako předávané mu znalosti o rytířských ctnostech (být statečný, zbožný, pečovat o čistotu erbu, vládnout zbraní) - to vše již mladý kralevic znal. Byl to jen krůček k tomu, aby si na bitevním poli vybojoval - díky své neporazitelnosti - přívlastek „železný.

A právě rytířská kultura byla natolik koncepční, že by bylo nemyslitelné, aby v této době nevznikl také adekvátní ideál panovnický, který by neodpovídal soudobému životnímu stylu. Všechny vlastnosti, podobně jako dovednosti rytíre, podmiňovaly tento rytířský ideál panovníka a zároveň se v něm bezesporu odrážely. A za rytířský typ vládce Přemysl Otakar II. zcela určitě platil. Ale mnohdy jistě překročením hranic...

Ač jde o panovníka, tedy o osobnost, jež v toku „velkých dějin“ politických, kulturních nebo hospodářských zanechala nesmazatelnou a výraznou stopu, je třeba jistě připomenout, že mnohé př́ivlastky, které krále ve vyprávěcích pramenech „zdobi““ všemi jen myslitelnými superlativy, byly velice záhy narativně zkresleny. ${ }^{27} \mathrm{~V}$ daném konkrétním př́padě se pramenně odrazily četné superlativy ohledně „velikosti a bohatství osobnosti zejména v přívlastcích „železný a „zlatý. Obě přídavná jména se stala kategoriemi stanovenými prŕslušnými vlastnostmi kovů, at svou tvrdostí, pevností, váhou, barvou, kvalitou. Autoři pramenů v panovníkovi spatřovali jak sílu, udatnost a bohatství, tak i oddanost bohu a jeho zástupcům na zemi. Reflexivně ho tak ztotožnili s obhajobou šlechetnosti a mravním étosem své doby; otevřeli tak ale pozdějšímu podání, potažmo dějepisectví, dveře pro klišé, šablonovitost, jakož i nálepkování. Narátor, uchopující v rámci zadání osudy člověka, i takzvaného němého, neznámého, zároveň jednoznačně určuje daný lidský příběh, promítá do textu začasté mocenské kalkulování, mnohdy vyplývající z objednávky, současně však odráží svou vlastní zkušenost, již (dá se tvrdit, že s vysokou pravděpodobností) promítá do př́běhu „svého hrdiny“.

Příkladně Zbraslavská kronika, jež je hlavním literárním pramenem - historickým zpracováním pro konec 13. století a zejména pak pro první čtvrtinu 14. století -, a to z pohledu dvou členů konventu cisterciáckého duchovenstva žijícího na Zbraslavi, zamlčuje uvalení církevní klatby papežem na krále Přemysla Otakara II. za nepřátelství vůči Rudolfu I. Habsburskému. Pro život Přemysla Otakara II. ji můžeme považovat za prvořadý písemný doklad (za předpokladu, že neodhlížíme od již zmíněného latinsky psaného literárního pramene Annales pragenses a Annales Ottacariniani), i přesto, že a) předmětem Zbraslavské kroniky je především život syna Přemysla Otakara II., Václava II. (1271-1305), zakladatele Zbraslavského kláštera (1292), dále například události související s vládou Václava III. (1301-1306) či líčení oslavující Lucemburky v čele českého státu (do roku 1338); b) byla napsána až po smrti Václava II., tedy po roce 1305.

27 Jejich autoři - kronikáři, letopisci - sice usilovali více či méně přesně doložit fakta, známá jim především z vyprávění, ústního podání, svých předchůdců, nicméně kolektivní pamět už po několika generacích není schopna uchovat autentický životopis významné osobnosti. Historiografie svými narativními aspekty dokáže zachytit širší souvislosti, je však třeba připustit, že pohled kronikáře-„,současníka“ je v jisté fázi spíše pohledem „politologa“, který význam té či oné události zpravidla rovněž hodnotí, leč často bez dostatečného časového nadhledu. Narátoři tak zakládají interpretační linku, kterou svým přirozeným způsobem změny politické, ekonomické, liturgické i obchodní zachycují, príijímají a hodnotí. Tím - byt๋ v dobré víre - zakládají bázi pro vytvoření mýtu, jenž nikdy nebyl - a ani nemohl být - racionálním systémem. Podstatou mýtu nebylo pochopit, nýbrž uvěřit, dát víru. 
Jiné prameny pak nepovažují za významné zmínit mladický „protiotcovský odboj“, další se neztotožňují s jednáním v souvislosti s intimními otázkami manželství, respektive rozvodu, samozřejmě dle římského práva.

\section{A co zrcadlo francouzských Annales?}

Reprezentant první generace Annales Marc Bloch v knize Králové divotviorci přisuzuje královské moci „nadpřirozenost“. ${ }^{28}$ Představuje soudobou víru v divotvorné schopnosti středověkých panovníků Anglie a Francie a zmiňuje zánik této „kolektivní iluze“ na sklonku novověku. Tyto atributy lze jistě „vystopovat“ i u zpracování obrazu osobnosti krále Přemysla Otakara II., jež se stala archetypem středověké literatury nejen české provenience. Ideál středověkého panovníka konce 13. století jako mocného, zbožného, štědrého, znalého válečnického umění skrývá z nejznámějších děl třeba staročeská Alexandreida. ${ }^{29}$ Též jednou z historických postav Dantovy Božské komedie z přelomu 13. a 14. století je i postava Přemysla Otakara II. ${ }^{30}$ Dlužno podotknout, že cesta k obdivu a superlativưm uváděným jednotlivými kronikáři nebyla nikterak jednoduchá a snoubí se tak či onak s lidským př́iběhem. Připomeňme namátkou...

Odboj proti otci... Někteří z českých pánů nebyli, jak už to bývá, spokojeni s vládnutím Přemyslova otce, krále Václava I. Ve svém odporu získali na svou stranu i prince a 31. července 1247 jej zvolili „mladším“ králem. Že si „koledovali“, je jasné. Václav I. byl překvapen, naoko volbu přijme, nicméně připraví odvetu. Střet u Mostu na jaře 1248 a desetidenní ostřelování Pražského hradu praky je jen logickým vyústěním. Přemysl se vzdá, koří se a slíbí poslušnost. ${ }^{31}$ Poražení šlechtici jsou po mši pohoštěni symboly nemilosti - čerstvými rybami s useknutou hlavou.

I vidina připojení rakouských zemí má své ale... Devatenáctiletý mladík si bere zhruba dvaapadesátiletou Markétu Babenberskou. Kolem svatby možná bylo hodně slávy, ale jistě i spousta úšklebků: jak to bude s nadějemi na mužského potomka a následníka? Přemysl patrně už od počátku kalkuloval s rozvodem, vždyt’ léta odkládal společnou korunovaci.

Přibík Pulkava, jeden z kronikářơ, situaci vidí jednoznačně: „Kromě toho je třeba vědět, že Přemysl, ačkoli měl svou již zmíněnou ženu Markétu několik let, přece s ní nemohl zplodit děti, protože byla neplodná. Markéta, chtějíc vyzkoušet príčinu této neplodnosti, souhlasila, aby její manžel Přemysl sdílel lože s jednou z jejích urozených dívek, dcerou jakýchsi šlechticů $z$ Künringu. S tou zplodil syna, jemuž dal jméno Mikuláš..."32

Kromě Mikuláše, budoucího opavského vévody, se ze vztahu s mladičkou dvorní dámou, zvanou podle sestř̌ihu vlasů „Palcéřík“, narodily dvě (možná tři ${ }^{33}$ ) dcery.

28 Marc Bloch, Králové divotviorci: studie o nadprirozenosti přisuzované královské moci, zejména ve Francii a Anglii, Praha 2004, s. 37nn. Koncepce posvátné královské moci a „víra v léčivou moc králů a knížat byla s jistotou rozšírena i v Německu“. Ibidem, s. 133.

29 Alexandreida, eds. Albert Pražák - Václav Vážný, Praha 1947, s. 27n., s. 33-35.

30 Jaroslav Vrchlický, Božská komedie II. Očistec, Praha 1929, s. 39n.

31 František Pražský, Kronika, in: Kroniky doby Karla IV., ed. Marie Bláhová, Praha 1987, s. 60.

32 Příbík z Radenína, řečený Pulkava, Kronika česká, in: Kroniky doby (pozn. 31), s. 368.

33 Ibidem. 
A do třetice... Když po rozvodu s Markétou ze scény zmizela i Palcéŕík (odjela s Markétiným doprovodem), uzavřely se také otázky uherské. Definitivní rezignace Uher byla stvrzena svatbou s vnučkou uherského krále Bély IV., do té doby největšího Přemyslova neprrítele. „Čekalo, čekalo srdce naše s radostí na návrat Váš. K jeho uvitání rozhodly jsme se s touhou v srdci i duši pospíšiti vstříc na místo i v den, na které jste ustanovil, že po prvé vstoupite na pomezí Čech. Tam necht’ predeběhne nás tento lístek a uvitá Vás v radosti a jásáni, “34 píše prostřednictvím svého dvorského písaře Kunhuta Uherská Přemyslovi před jeho návratem $z$ válečné vřavy.

Primárním cílem francouzské školy Annales, ${ }^{35}$ typické provázáním historiografie s dalšími humanitními disciplínami, bylo chápání historie nejenom z hlediska politických a diplomatických dějin, ale také - a především - dějin hospodářských a sociálních a též dějin každodennosti. Patřilo k tomu i vnímání struktur - pojmy času či tělesnosti - hluboce zakořeněných ve společnosti. Nabízí se jistě otázka, vyslovená na sklonku minulého století Andrém Burguièrem, je-li historická antropologie výsledkem vnitřního vývoje historického myšlení, anebo interdisciplinárním „transplantátem“" ${ }^{36}$

Jak už jsem zmínila, 13. století je samo o sobě obdobím, kdy došlo k velmi rychlému rozvoji ve všech sférách života. Lze tak dát, domnívám se, za pravdu jednomu z významných historiků druhé generace školy Annales - Fernandu Braudelovi ${ }^{37}$ - s jeho trojí úrovní historického času i s geografickým zdůrazněním: literární prameny s těžištěm do třetí čtvrtiny 14. století, jež zachycují období života Přemysla Otakara II., jsou kompaktními zdroji pro sledování procesů v řádu událostí, cyklů, politických i geografických struktur. ${ }^{38}$ Snáze si uvědomíme, že neexistuje jen jeden historický čas a že lze vnímat Braudelovo rozlišení tří historických časů: a) čas dlouhého trvání - pro člověka nepostižitelné klimatické či geologické změny (takřka nehybné dějiny); b) čas konjunktur - odvíjející se dějiny hospodářských, sociálních a politických struktur (např́klad čas demografického vývoje; čas agrární...); c) čas událostní - rychlý čas politických událostí -, bitvy, vlády, významné osobnosti...

V kontextu vlády Přemysla Otakara II. pak zmiňme zlepšení statusu českých zemí v mezinárodní politice, rozvoj obchodních kontaktů ve spojitosti s českým stříbrem a výbojnou „přeszahraniční politikou (válečná tažení do Prus či Bavor). Ve vnitropolitické oblasti šlo zejména o a) zvyšování úrovně a zdokonalování ekonomicko-organizační a správní roviny; b) demografický nárůst, tím vyvolané vyšší hospodářské potřeby; c) postupný zánik hradské soustavy, tedy rané územní organizace; d) nahrazení tohoto systému městskými obcemi, potažmo městy, a tím započatá a za vlády Přemysla Otakara II. vrcholící „,vnitřní a vnějši“ kolonizace (respektive koncepce nového osidlování v kontextu zemědělské evoluce) nových míst, někdy i odlehlejších od starého sídelního

34 Bedřich Mendl, Listy královny Kunhuty králi Přemyslovi, Praha 1928, s. 35. - Viz též Jan Bauer, Tajné lásky českých králů a královen, Frýdek-Místek 2011, s. 73.

35 Pavla Horská - Martin Nodl et al., Francouzské inspirace pro společenské vědy v českých zemích, Cahiers du CeFReS 29, 2003, s. 5nn.

36 André Burguière, L'anthropologie historique et l'école des annales, Réflexions historiographiques XXII, 1999, https://journals.openedition.org/ccrh/2362, vyhledáno 5. 12. 2020 [nepag.].

37 Fernand Braudel, Dlouhé trvání, Cahiers du CeFReS 8, 1995, s. 143-188.

38 Srov. ibidem, s. 148. Kromě „překotného a dramatického líční tradiční historie, zaměrené na krátký časový úsek, historické postavy a jednotlivé události“, jak Braudel nahlíží krátkodobé události, lze např́klad v análech typu Druhých pokračovatelư Kosmových zjistit záměrné zaznamenávání cyklických úseků týkajících se kupř́kladu zemědělských či demografických faktů. 
území, rozkládajícího se v úrodných polohách, především u vodních toků. Krok za krokem překračování hranic...

Domnívám se, že dle metody výkladu Jacquesa Le Goffa v Kultuře středověké Evropy ${ }^{39}$ lze shrnout poznatky středověkých kronikářo a letopisců ohledně např́klad hospodářství, každodenního života, ovšem již v kontextu revidovaného pohledu, tedy v širších souvislostech. ${ }^{40}$ Mou pozornost poutá i koncepce „nových dějin mentalit“, sympatický mi byl a je i autorův záměr nahlížet prameny „novými aspekty (...), metodami sociologickými, etnografickými a antropologickými ““ ${ }^{41} \mathrm{~S}$ Rogerem Chartierem ${ }^{42}$ lze též klást důraz na korelace procesů a jevů, na kontinuity dějinného procesu i na narativní konstrukci jakožto rekonstrukci minulosti, jak byla („history“versus „story“, historie versus prŕběh). Vždyt” námět osudu Přemysla Otakara II. nemizí ani v dalších stoletích. Problematika se odráží i v opeře či divadelních hrách, kupř́íkladu dramatech všeobecně známého rakouského dramatika Franze Grillparzera. ${ }^{43}$

Jak je z př́spěvku, doufám, zřejmé, má práce na základě vyprávěcích pramenů zamýšlí verifikovat, do jaké míry při tvorbě analistického či kronikářského záznamu o Přemyslu Otakarovi II., nezaměnitelné postavě českých dějin, zasahovaly do zachycení a ztvárnění jeho obrazu mocenský kalkul a topoi velkého panovníka nebo naopak mučedníka, a zda se mimo jiné nemohlo jednat o až účelově směřovanou transformaci faktů ze světa světského do světa sakrálního. I nadále se domnívám, že pomocí přístupů francouzské školy Annales, vytyčených jednotlivými generacemi historiků, lze na tuto otázku, i další podotázky, najít odpověd'. Doufám, že další badatelské kroky, jež mi zbývající akademické studium snad otevře, alespoň některé otázky zodpoví.

\section{SUMMARY}

\section{The power calculus as a constant and a variable of human story. The concept of royal power, the archetype and the fate of Premysl Otakar II in the mirror of the school Annales}

I took this text as an opening to my dissertation, in which I want to focus on my basic considerations when entering the issue and also focus on some observations from the analysis of literary sources, especially from a historical anthropological point of view (representatives of the Annales school). Given the understanding of history from the perspective of the deep-rooted structures that govern the society (and, first of all, the sovereign), I want to deduce on the basis of written sources: a) aspects which describe

39 Le Goff, Kultura (pozn. 6), s. 13-25. - Idem, Hledání (pozn. 2), s. 29n.

40 Připomeňme, že středověkou ekonomiku má Le Goff za stagnující, dokud se odehrává v mantinelech feudálních ekonomických pravidel. Ve chvíli, kdy města pozdního středověku „etablují pružnější obchodní a peněžní vztahy“, může být, jak konstatuje, „tato uzavřenost prolomena“. Le Goff, Peníze (pozn. 8), s. 30nn., zvl. s. 46-47.

${ }^{41}$ Le Goff, Kultura (pozn. 6), s. 741.

42 Roger Chartier, Na okraji útesu, Červený Kostelec 2010, s. 79-98. - Jan Horský - Daniela Tinková, Roger Chartier: nové intelektuální a kulturní dějiny jako historiografická odpověd' na výzvy postmoderních kritik, in: Jiří Hanuš - Radomír Vlček (eds.), Historik v proměnách doby a prostředí 20. století, Brno 2009, s. 26-55.

43 Franz Grillparzer, Sláva a pád krále Otakara, Praha 2019, s. 113-262. 
the sovereign's character in the view of demands fullfilments on him (moral and others, for example the opposition to his father, an illegitimate relationship, conflict with the nobility); or b) attributes such as his deeds and circumstances that led him to these deeds ("crossing borders" as "marketing campaigns", for example war campaigns to Prussia or Bavaria). I continue to believe that the approaches of the French Annales school, set out by various generations of historians, can be used to answer this question, as well as other sub-questions.

\section{Výběrová bibliografie}

Marc Bloch, Králové divotvůrci: studie o nadpřirozenosti přisuzované královské moci, zejména ve Francii a Anglii, Praha 2004.

Fernand Braudel, Dlouhé trvání, Cahiers du CeFReS 8, 1995, s. 143-188.

Zdeněk Fiala, Přemyslovské Čechy: Český stát a společnost v letech 995-1310, Praha 1975.

Fontes rerum Bohemicarum II-V, ed. Josef Emler, Praha 1874-1893.

Jan Horský - Daniela Tinkova, Roger Chartier: nové intelektuální a kulturníi dějiny jako historiografická odpověd’ na výzvy postmoderních kritik, in: Jiří Hanuš - Radomír Vlček (eds.), Historik v proměnách doby a prostředí 20. století, Brno 2009.

Wojciech Iwańczak, Po stopách rytírských přiběhů, Praha 2001.

Josef Janáček, Přemysl Otakar II., in: idem, Velké osudy, Praha 1972.

Jacques Le Goff, Hledání středověku, Praha 2005.

Jacques Le Goff, Penize ve středověku: historicko-antropologická studie, Praha 2012.

Josef Žemlička, Přemysl Otakar II.: král na rozhraní věkư, Praha 2011. 